\title{
Micro-titration of depot neuroleptic dosages
}

\author{
J. Birch
}

Depot neuroleptic treatments can be compromised by sids-eflects unacceptable to users or, more serlousty, by tordive dyskineela (ID). Nouroleptic dosages can be lowered to increase acceplabillty and decrease the incidence of TD, but with a greater likelthood of relepee. One argument proposes that many patients changing to lower dosages breck down because withdrawal from a neuroleptic is streseftul in liself. Resecirch sugoests that withdrowal regimes should be radically coutious. A computer tool is oflered which can ald clinicions in colculating small rectuctions.

The effect of stopping long-term neuroleptic use, especially in schizophrenia, has been widely researched; Gilbert et al (1995) review 66 such studies in a dedicated edition of Archives of General Psychiatry. The outcome for simple cessation seems unequivocal, with half of withdrawn patients relapsing compared with only one-sixth of those patients continuing on medication. Gilbert et al note the withdrawal process used in each study, where this information is available. Two-thirds $(42 / 66)$ of the studies reported stopping neuroleptic medication immediately: the maximum time allowed for medication withdrawal was 60 days. This might seem to suggest that the actual process of neuroleptic withdrawal is seen as non-problematic. Similarly, Schooler (1993) reviews studies of intermittent and low-dose strategles and does not comment on the possible effects of abrupt versus gradual change in neuroleptic cover.

By contrast, Mosher \& Burti (1989), arguing that dopamine blockade has lasting effects on receptor sites, propose that patients who have used neuroleptics over many years exhibit a discrete withdrawal syndrome when attempts are made to stop their drug. They propose that long-term users of neuroleptics can no longer experience a neuroleptic-free environment without intolerable levels of arousal. Consequently they advise that such patients should always be prescribed a residual dose of neuroleptic, no matter how successfully these patients appear to have survived dosage reduction. If one accepts the logic of this position then it follows that reductions in depot medication should be cautious and fractional. Indeed this is the position which Gilbert et al (1995) adopt when commenting on the clinical implications of their study. They draw attention to a preliminary report by Green (1992) which suggests that modest titration downwards of neuroleptic doses can result over time in major reductions in drug use but without the risk of relapse associated with abrupt cessation.

Inderbitzin et al (1995) have also reported the success of a similar strategy. An experimental group of long-term depot users had their dose reduced to $50 \%$ over five months by cutting $10 \%$ of the starting dose each month. Comparison with a control group over 12 months showed no signiffcant differences in symptoms or relapse rates. Extrapyramidal symptoms increased in the control group, but decreased in the experimental group. Tardive dyskinesia increased in both groups, but significantly less in the reduced-dose group. Among the nine patients who relapsed (four reduced-dose and five control) the authors surmise that use of recreational substances and serious psychosocial stresses were more influential than neuroleptic use. They offer a clinical impression that patients using the reduced dose might be more susceptlble to the effects of missing a single injection.

\section{Practical application of dose titration}

Such findings encourage the practice of regular but cautious depot reductions over time. However, depot dose titration poses a practical difficulty. Most depot drugs are marketed only as one standard and one concentrated preparation. In my experience this has inclined English prescribing towards relattvely crude adjustments in dosage, typically of $25 \%, 33 \%$, or $50 \%$. Fine tuning of dosages by $10 \%$ or $15 \%$ demands a good deal of trial and error calculation in order to artive at the required combination of preparation strength, dosage interval, and injection volume. This has led me to develop a computer program which dertves these values, thus saving time and improving accuracy. Table 1 shows part of a typical print copy designed for prescribers. It will be seen that this method yields a number of alternatives, or near alternatives, for any one 
Table 1. Depot medication dosage calculator

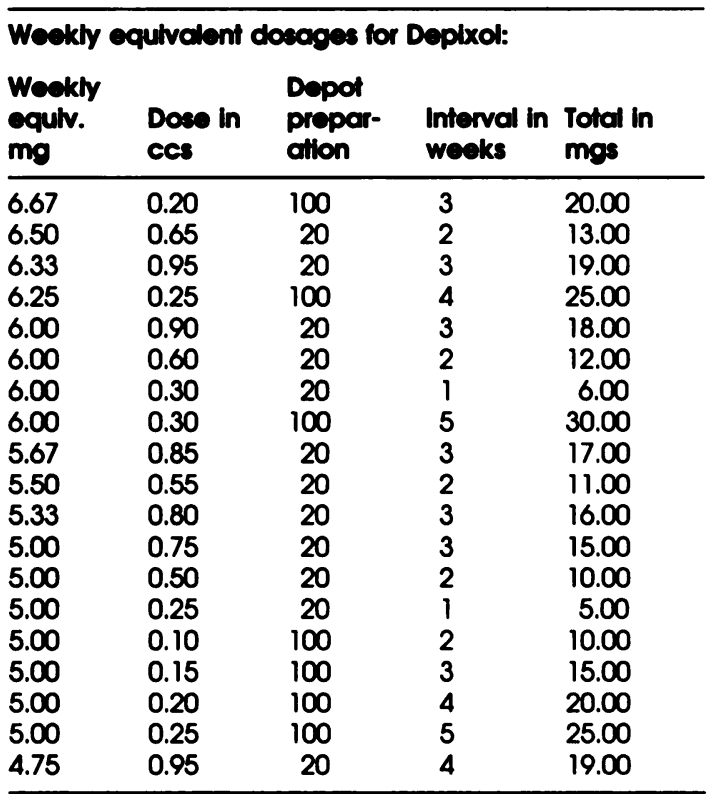

Table 2. Volumes to draw up for injections of Depixol

\begin{tabular}{|c|c|c|c|c|c|}
\hline $\begin{array}{l}\text { Tolal } \\
\text { does }\end{array}$ & $\begin{array}{l}\text { Dose in } \\
\text { ccs }\end{array}$ & $\begin{array}{l}\text { Depot } \\
\text { preper- } \\
\text { citon }\end{array}$ & $\begin{array}{l}\text { Tolal } \\
\text { dose }\end{array}$ & $\begin{array}{l}\text { Dose in } \\
\text { ccs }\end{array}$ & $\begin{array}{l}\text { Depof } \\
\text { preper- } \\
\text { cilon }\end{array}$ \\
\hline $\begin{array}{r}2.00 \\
4.00 \\
6.00 \\
8.00 \\
10.00 \\
12.00 \\
14.00 \\
16.00 \\
18.00 \\
10.00 \\
20.00 \\
30.00 \\
40.00 \\
50.00 \\
60.00 \\
70.00 \\
80.00 \\
80.00 \\
90.00\end{array}$ & $\begin{array}{l}0.10 \\
0.20 \\
0.30 \\
0.40 \\
0.50 \\
0.60 \\
0.70 \\
0.80 \\
0.90 \\
0.10 \\
0.20 \\
0.30 \\
0.40 \\
0.50 \\
0.60 \\
0.70 \\
0.80 \\
0.80 \\
0.90\end{array}$ & $\begin{array}{c}20 \\
20 \\
20 \\
20 \\
20 \\
20 \\
20 \\
20 \\
20 \\
100 \\
100 \\
100 \\
100 \\
100 \\
100 \\
100 \\
100 \\
100 \\
100\end{array}$ & $\begin{array}{r}3.00 \\
5.00 \\
7.00 \\
9.00 \\
11.00 \\
13.00 \\
15.00 \\
17.00 \\
19.00 \\
15.00 \\
25.00 \\
35.00 \\
45.00 \\
55.00 \\
65.00 \\
75.00 \\
85.00 \\
85.00 \\
95.00\end{array}$ & $\begin{array}{l}0.15 \\
0.25 \\
0.35 \\
0.45 \\
0.55 \\
0.65 \\
0.75 \\
0.85 \\
0.95 \\
0.15 \\
0.25 \\
0.35 \\
0.45 \\
0.55 \\
0.65 \\
0.75 \\
0.85 \\
0.85 \\
0.95\end{array}$ & $\begin{array}{c}20 \\
20 \\
20 \\
20 \\
20 \\
20 \\
20 \\
20 \\
20 \\
100 \\
100 \\
100 \\
100 \\
100 \\
100 \\
100 \\
100 \\
100 \\
100\end{array}$ \\
\hline
\end{tabular}

required dose. The values, taken from previously computed data tables, can be displayed for a clinician with direct access to a computer, or tables can be printed as hard copy for use off line.

Initially the approach is demanding of staff who administer the injections, often calling for unfamiliar doses. For this reason the program also includes tables of volumes to draw up for standard and concentrated preparations. The Depixol table is reproduced by way of example (Table 2). A standard $1 \mathrm{ml}$ syringe is assumed.

The calculator has enabled me to advise patients on small reductions in depot medication with ease. This is not so much a new strategy for me as an enhancement of my existing practice. From the patient's point of view one can offer a variety of weekly equivalent doses which allow a choice between a large injection at long intervals versus a small injection at short intervals.

The depot injection calculator program is written in Visual Basic ${ }^{\circ}$ and runs in the Windows $^{\oplus}$ environment. It displays dosage tables for Modecate, Depixol, Clopixol, and Haldol. I am making it avallable to individuals without charge, for their own use: to recetve a copy please send a

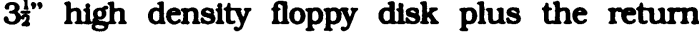
postage. Eight sample printed tables, a pair for each depot preparation, can be obtained from the author in return for an S.A.E.

\section{References}

GILBERT, P. L., HARRIS, M. J., MCADAMS, L. A., et al (1995) Neuroleptlc withdrawal in schizophrenic patients: a review of the literature. Archives of General Psychiatry. 62. 173-188.

Green, A. I. Faraone, S. V., Brown, W. A. et al (1992) Neuroleptic Dose Reduction: Cinical and Neuroendocrine Effects. 31st Annual Meeting of the American College of Neuropsychopharmacology. Puerto Rico.

INDERBITZIN, L. B., LEWINE, R. J., SCHEULR-GIKFG, G., et al (1994) A double-blind dose-reduction trial of fluphenazine decanoate for chronic, unstable, schizophrenic patients. American Journal of Psychiatry, 181, 1753-1759.

MoshIER, L. R. \& BURT, L. (1989) Community Mental Health: Princtples and Practice. New York: W. W. Norton.

SCHOOLER, N. (1993) Reducing dosage in maintenance treatment of schizophrenia: review and prognosis. Brttish Journal of Psychiatry. 165 (suppl. 22), 158-165.

SMITH, R. C. (1994) Lower-dose therapy with traditional neuroleptics in chronically hospitalized schizophrenic patients. Archives of General Psychiatry, 81, 427-429.

Jim Birch, North Shields CMHT, 26a Hawkeys Lane, North Shields, Tyne \& Wear 